\title{
Between Identity and History: Giovanni Antonio Valtrino and His Vocazioni meravigliose alla Compagnia di Gesù
}

Author: Irene Gaddo

Source: Engaging Sources: The Tradition and Future of Collecting History in the Society of Jesus (Proceedings of the Symposium held at Boston College, June 11-13, 2019)

Edited by: Cristiano Casalini, Emanuele Colombo, and Seth Meehan

ISBN: 978-1-947617-09-4

Published by: Institute of Jesuit Sources

Originally Published: March 1, 2021

https://doi.org/10.51238/ISJS.2019.03

Provided in Open Access by the Institute for Advanced Jesuit Studies at Boston College.

The Institute of Jesuit Sources, specializes in preserving, maintaining, and expanding for scholars around the world important texts and studies in Jesuit history, spirituality, and pedagogy.

Visit our website at https://jesuitsources.bc.edu 


\title{
Between Identity and History: Giovanni Antonio Valtrino and His Vocazioni meravigliose alla Compagnia di Gesù
}

\author{
IRENE GADDO
}

\section{Introduction}

Giovanni Antonio Valtrino (1556-1601) began to assemble his Vocazioni meravigliose alla Compagnia (Marvelous vocations to the Society) ${ }^{1}$ just after he entered the Society of Jesus in the mid-1570s, one of the most disruptive periods in the history of the old Society. During the generalships of Everard Mercurian (in office 1573-80) and Claudio Acquaviva (in office 1581-1615), long-term elements of instability and turmoil erupted in a crisis so general and profound that it shook the whole Ignatian edifice and gave way to a deep "transformation."2 In the wider European context, the wars of religion and power dynamics among competing states triggered new tensions, and the interests and religious rivalries of the period often involved the Society of Jesus. On different occasions, political and religious powers attempted to meddle in the order's affairs and revise its governance and structure; from the inside, controversies elicited discussions and some open rebellions, especially from Spain and Italy, which called for the Society's organizational and spiritual features to be reformed. ${ }^{3}$ Nonetheless, the Society continued to grow in numbers and wealth: membership increased, as did the order's educational institutions

\footnotetext{
* I would like to thank the anonymous reviewer for the very useful suggestions and comments. Some I have tried to implement while others I had to put off; but, as someone once wisely told me, "every essay cannot be about everything."

${ }^{1}$ Roman Jesuit Archives (Archivum Romanum Societatis Jesu or ARSI), Fondo Gesuitico, MS 2, Vocazioni meravigliose alla Compagnai raccolte dal P. Gio. Antonio Valtrino. With the exception of Adriano Prosperi, who studied some parts of it in his La vocazione: Storie di gesuiti tra Cinquecento e Seicento (Turin: Einaudi, 2016), Valtrino's collection has thus far remained unpublished. However, a full, annotated transcription is now available as an appendix to my Vocazione e identità gesuitica in Giovanni Antonio Valtrino (1556-1601) (Padua: Padua University Press, 2019), 77157.

${ }^{2}$ Michel de Certeau was the first to point out the pervasiveness of the late sixteenth-century crisis that hit the Society and almost overcame it; he spoke of a deep "transformation" of the Ignatian institution after that crisis had gone. See Michel de Certeau, Le lieu de l'autre: Histoire religieuse et mystique (Paris: Gallimard-Le Seuil, 2005 [1973]), 155.

${ }^{3}$ Michela Catto, La Compagnia divisa: Il dissenso nell'ordine gesuitico tra '500 e '600 (Brescia: Morcelliana, 2009); Esther Jiménez Pablo, La forja de una identidad: La Compañia de Jesús (15401640) (Madrid: Ediciones Polifemo, 2014); Guido Mongini, "La crisi della Compagnia di Gesù all'epoca di Acquaviva: Pedro Ribadeneira e la definizione dell'identità gesuitica," in Padre Claudio Acquaviva S.J. preposito generale della compagnia di Gesù e il suo tempo, ed. Martin Maria Morales and Roberto Ricci (L'Aquila: Libreria Colacchi, 2018), 183-229.
}

https://doi.org/10.51238/ISJS.2019.03

(C) Institute of Jesuit Sources, 2021 
and residences and the Jesuits' duties in and outside Europe. ${ }^{4}$ In such an unstable and hostile climate, the Society's very existence was at stake. At the turn of the sixteenth century, the concern for the order's cohesion and the desire for a return to the fundamentals of the Society at its origins prevailed among the Jesuit hierarchy. Acquaviva sought to resolve the crisis by acting to contain external interference while limiting internal dissent by reinforcing the Society's unity and its image as a single, coherent, and harmonious body.

This is the historical background against which Valtrino's work has to be read. The Vocazioni meravigliose alla Compagnia di Gesù is one of the oldest collections authored by a Jesuit specifically on the subject of vocation. At a time when the Society was experiencing such a severe crisis, one concerning its identity, the issue of the Jesuit vocation acquired particular relevance. Largely unexplored, the topic is complex and requires deeper research. Some historians have begun to examine aspects of the Jesuit vocation from new perspectives that will hopefully stimulate further explorations, ${ }^{5}$ and it is in this renewed historiographical interest that the current essay intends to participate. Without pretending to arrive at definitive answers, the essay aims to shed some light on the process of Jesuit identity-building in a crucial period of the old Society's history.

\section{"A Man of Bright Intelligence and Much Erudition"}

According to a brief entry in the Diccionario histórico de la Compañia de Jesús (Historical dictionary of the Society of Jesus), ${ }^{6}$ Valtrino was born in Rome in 1556. On October 18, 1574, he entered the Society of Jesus and attended the Roman College, where he took courses of philosophy and theology. While completing his studies, in the following three years he also carried out a number of educational tasks, teaching the lower classes of grammar, rhetoric, and humane letters before serving as the praefectus studiorum humanitatis (prefect of humanistic studies) for the next triennium. Between 1587 and 1591, he moved to Sicily, where he made his third probation in Messina. Back on the continent, he had several other teaching duties: he taught holy scripture at the Roman College (1593-96), lectured casus conscientiae (cases of conscience) in Siena and Florence (1596-97 and 1599) and then again

\footnotetext{
${ }^{4}$ In 1581, the Society of Jesus had more than five thousand members, a figure that had more than doubled by the turn of the century, reaching 13,112 in 1615. See Sabina Pavone, I gesuiti dalle origini alla soppressione (Rome: Laterza, 2004), 14-16, 33-44.

${ }^{5}$ For innovative research on the topic, see the contributions in "Vocazioni e scelta di vita nella prima età moderna. Il caso della Compagnia di Gesù," ed. Emanuele Colombo, Pierluigi Giovannucci, and Guido Mongini, Rivista storica italiana 132, no. 3 (2020).

${ }^{6}$ Antonio M. Pignatelli, "Valtrino, Giovanni Antonio," in Diccionario histórico de la Compañía de Jesús: Biográfico-temático (hereafter DHCJ), ed. Charles E. O’Neill and Joaquín M. Domínguez (Rome: Institutum Historicum Societatis Iesu, 2001), 4:3881.
} 
in Rome. Here, he became professed of three vows on January 3, 1599 and died in Loreto on August 31, $1601^{7}$.

Apart from this limited information, we know very little about Valtrino's life. His origins and family background are obscure, and it is not clear how and why he decided to join the Society of Jesus. It is likely that the young Giovanni Antonio made his resolve at an early age through his acquaintance with Jesuit circles, probably attending the free classes the Jesuits set up and ran in Rome in the second half of the sixteenth century. ${ }^{8}$ Far more attested are Valtrino's activities "beyond the threshold." In the Roman College, the model institution for the whole Jesuit educational system, he could find the ideal setting to develop his scholarly aptitude, which he successfully applied to the studia humanitatis (humane letters). First as a student and later as a professor, Valtrino took part in defining the Society of Jesus as a teaching order, a process that had already been started by Ignatius of Loyola and was accomplished under his successors with the proliferation and institutionalization of an international network of colleges, the success of which was attested by the high rate of student enrollments. ${ }^{10}$ During his generalship, Acquaviva took particular care of educational policy, which culminated in the official promulgation of a set of norms and rules, the Ratio studiorum (Plan of studies) in 1599.

As a brilliant scholar, Valtrino contributed to this success. In the Bibliotheca scriptorum Societatis Jesu (Library of Jesuit writers), the aged Jesuit Pedro de Ribadeneyra (1526-1611) referred to Valtrino as a "vir candidi ingenii multaeque eruditionis" (a man of bright intelligence and much erudition), recognizing his scholarly skills, knowledge, and proficiency. ${ }^{11}$ Presumably due to his literary abilities and reliability, Valtrino was involved in a new enterprise that Acquaviva set up in the early years of his generalship, namely the print edition of the Litterae annuae (Annual letters). Historians have stressed the key role of epistolography as an "organic principle" of the Society of Jesus from its very foundation, which helps to explain the vertiginous increase of written communication during the Acquaviva era, when the Society underwent a tremendous expansion in terms of men and

\footnotetext{
${ }^{7}$ Biographical details are confirmed by the entries of the so-called Schedario Lamalle in ARSI.

${ }^{8}$ This is what can be assumed from Jean Goetstouwers, S.J., "La vie de S. Stanislas Kostka par le P. Jean-Antoine Valtrino," Archivum historicum Societatis Iesu 1 (1932): 254-75, here 255.

${ }^{9}$ The expression refers to the noteworthy and informed essay by Miriam Turrini, "Poco oltre la soglia: Racconti autobiografici di aspiranti gesuiti a metà Seicento," Studi storici 55, no. 3 (2014): 585-614.

${ }^{10}$ For the assimilation of education into the Society's ministry, see Cristiano Casalini, "Rise, Character, and Development of Jesuit Education: Teaching the World," in The Oxford Handbook of the Jesuits, ed. Ines G. Županov (New York: Oxford University Press, 2019), 153-76.

${ }^{11}$ Bibliotheca scriptorum Societatis Jesu: Opus inchoatum a R.P. Petro Ribadeneira eiusdem Societatis theologo, anno salutis 1602, continuatum a R.P. Philippo Alegambe, ex eadem Societate, usque ad annum 1642 (Rome: Ex Typographia Iacobi Antonii de Lazzaris Varesii, 1676), 401.
} 
places. ${ }^{12}$ An instrument of government and a bond between the dispersed members of an increasingly far-flung organization and its Roman head, the regular exchange of letters also served to unify Jesuit corporate identity, providing that "union of souls" prescribed in the Constitutions. Moreover, letter-writing concurred to inspire "mutual consolation and edification" not only for Jesuits but also for a more general audience. The difficulty in managing the mounting flow of information led to the imposition of new strategies to avoid inefficiency and interruptions in the stream of communication between the peripheries and the center. The idea of printing the Litterae annuae was an answer to that need; compiled and printed in Rome, the first two issues for the years 1581 and 1582 were published in 1583 and 1584 and edited by the young Valtrino. ${ }^{13}$ Leaving aside a more detailed analysis, it will suffice here to stress that the work of editing the accounts that every province had to send yearly to the curia in Rome was not an easy task for one person alone. Processing the bulk of documentation, organizing information, and selecting the relevant facts and events to form one Latin text would have been an extremely labor-intensive activity. $^{14}$

Different from other forms of correspondence (e.g., governmental relations, missionary reports, and edifying epistles), the annual letters had initially been a form of writing ad intra, that is, only for the Society and its members. Jesuits had to document the results of their enterprises in every province and overseas mission, but above all to edify and console the brethren, showing the progress of the Jesuit apostolate and offering examples for moral emulation. Delays and losses influenced the quality and regularity of the exchange, so the Fourth General Congregation (1581) decided to issue a unified yearbook from Rome and dispatched it to each community. It is not clear why Valtrino was entrusted with that task. As noted above, his excellent school results and proficiency in letters brought him to the attention of his superiors, among whom was the general-to-be Claudio Acquaviva, master of novices and professor and rector of the Roman College at the time of Valtrino's entry. Valtrino fulfilled the demanding task ("donkey work," as it was defined). ${ }^{15}$ Not only did he edit the incoming provincial reports but he also processed all the information into a new text that was to provide the entire Society with

\footnotetext{
${ }^{12}$ Pierre Antoine Fabre, "Correspondence as an Instrument of Government: Continuities and Evolutions of the Epistolary Habitus in the Society of Jesus," in The Acquaviva Project: Claudio Acquaviva's Generalate (1581-1615) and the Emergence of Modern Catholicism, ed. Pierre-Antoine Fabre and Flavio Rurale (Chestnut Hill, MA: Institute of Jesuit Sources, 2017), 11-28.

${ }^{13}$ Respectively Annuae litterae Societatis Iesu anni MDLXXXI: Ad patres et fratres eiusdem Societatis (Rome: In Collegio eiusdem Societatis, 1583) and Annuae litterae Societatis Iesu anni MDLXXXII: Ad patres et fratres eiusdem Societatis (Rome: In Collegio eiusdem Societatis, 1584).

${ }^{14}$ For a more comprehensive analysis of the whole enterprise, see Markus Friedrich, "Circulating and Compiling the Litterae annuae: Towards a History of the Jesuit System of Communication," Archivum historicum Societatis Iesu, 77 (2008): 3-39.

15 "Res est asinini laboris," cited in Friedrich, "Circulating and Compiling the Litterae annuae," 24.
} 
a harmonious and successful narration of itself, according to the superior general's intention of promoting the cohesion of the order and sustaining the implementation of the Jesuit enterprises. ${ }^{16}$ After the edition of the second volume of annual letters, Valtrino moved to Naples to get some rest from his literary labors, as the dedication of an epicedium authored by his confrère Francesco Benci confirms. ${ }^{17}$ Once recovered, Valtrino was charged with a new task and sent to Sicily with the new Sicilian provincial, Father Ludovico Maselli, ex-superior of the Neapolitan province. ${ }^{18}$ After arriving in Sicily in late $1585,{ }^{19}$ Valtrino spent the following five years working as a teacher in local institutions, moving from Palermo to Monreale and lastly to Messina, where he was rector of the novitiate. Messina was the seat of the first Jesuit college ever founded, the Collegium Prototypum. Around fifty years after its foundation, in the late $1590 \mathrm{~s}$, the institution was in deep waters: besides persistent economic troubles, there were problems with internal discipline and rivalries among most of the fathers, who felt staunchly jealous of their local autonomies and were impatient with the central government in Rome. ${ }^{20}$ At the very beginning of Acquaviva's generalship, the confrontation with the Messinese community reached a critical point that only the abilities of the new general could contain, if not easily overcome. ${ }^{21}$ In such a restless context, Valtrino soon came to complain about his position, which required leadership qualities and administrative skills that he felt

\footnotetext{
${ }^{16}$ In this regard, it is no wonder that the first document issued by Acquaviva as superior general was a circular letter titled De felice progresso della Compagnia [On the merry progress of the Society], sent on June 28, 1581 to all the superiors of the order. See Alessandro Guerra, Un generale fra le milizie del papa: La vita di Claudio Acquaviva scritta da Francesco Sacchini della Compagnia di Gesù (Milan: Franco Angeli, 2001), esp. 90-92.

${ }^{17}$ Francesco Benci, Orationes et Carmina, cum disputatione de stylo et scriptione (London: Apud Ioan. Pillehotte, 1603 [1590]), 32-38. The author hoped that in the Neapolitan setting Valtrino would have recovered both his soul and body. Valtrino confirmed his good shape by letter, one of the few autographed epistles that have been identified: Giovanni Antonio Valtrino to Francesco Benci, Naples, May 10, 1584, Archivio Pontificia Università Gregoriana, MS 532, no. 79. I wish to thank Lorenzo Mancini of APUG for pointing this item out to me.

${ }^{18}$ Ludovico Maselli (1539-1604) had been professor and rector of the Roman College (1575-81) and finished his career as visitor of Poland (1588-93) and father assistant of Italy (1594-1604); see Ricardo García-Villoslada, Storia del Collegio romano dal suo inizio (1551) alla soppressione della Compagnia di Gesù (1773), Analectica Gregoriana 66, Series Facultatis Historiae Ecclesiasticae 2 (Rome: Apud aedes Universitatis Gregorianae, 1954), 322, 327, 329; Mario Scaduto, Catalogo dei gesuiti d'Italia 1540-1565 (Rome: Institutum Historicum S.I., 1968), 94.

${ }^{19}$ Valtrino's presence is confirmed among the fathers of the College of Palermo who in 1586 were asked to deliberate over the draft of the Ratio studiorum; see Monumenta pedagogica Societatis Iesu, vol. 6, Collectanea de Ratione studiorum Societatis Iesu (1582-1587), ed. Lázsló Lukács (Rome: Institutum Historicum Societatis Iesu, 1992), 4*.

${ }^{20}$ On the Messina college, see Mario Scaduto, "Le origini dell'Università di Messina," Archivum historicum Societatis Iesu 17 (1948): 103-59; Rosario Moscheo, "Istruzione superiore e autonomie locali nella Sicilia moderna: Apertura e sviluppi dello Studium urbis Messanae (1590-1641)," Archivio storico messinese 59 (2011): 75-221.

${ }^{21}$ On the tensions between Acquaviva and the Messina community, see Scaduto, "Le origini dell’Università di Messina," 122-26, 137.
} 
he did not possess. ${ }^{22} \mathrm{He}$ repeatedly pleaded with Acquaviva to give him permission to leave and return to Rome; after several refusals, he even asked to be sent on a mission to Japan, since even the most remote destination was better than Sicily to him. ${ }^{23}$ Eventually, the superior general acceded to those pleas, allowing Valtrino to apply his skills where they would be most profitable, but not in some faraway mission, as he did not meet the requirements. As the Sicilian sojourn had proven, Valtrino was not a suitable man for managerial tasks: he was a man of letters, and in that field, he would have found "his Indies" and worked fruitfully for "the greater glory of God." 24

\section{From Letters to History}

At the end of the summer of 1591, Valtrino returned to Rome. Back in his alma mater, he was entrusted with a new task more suitable for his inclinations and skills, as revealed in Virgilio Cepari's (1564-1630) foreword to his Life of the Blessed Aloysius Gonzaga (1606). Summoned to other duties, Cepari was temporarily forced to abandon his writing on Aloysius Gonzaga ${ }^{25}$ and handed all his notes and papers to Valtrino, who had "just [...] returned from Sicily to write the Chronicles of the Society." ${ }^{26}$ Having this documentation at his disposal, Valtrino resolved to carry out a biographical sketch of his young confrère. According to Cepari: "Although [Valtrino] had never met Aloysius, nonetheless he found that [Aloysius's] reputation as a saint was so great within the Roman College that he could not wait to describe all those things in the Chronicles but composed a biography of its own." Thus, soon after Gonzaga's death, Valtrino wrote one of the first works dedicated

\footnotetext{
${ }^{22}$ As far as we know, not one of Valtrino's letters has survived; what we know about his difficult Sicilian sojourn comes from copies of letters of Acquaviva in ARSI (infra, notes 23, 24).

${ }^{23}$ Although Valtrino's indipeta is listed in the ARSI catalog (ARSI, F.G. 733, 4), unfortunately the letter is missing; we only know it was dated 1589. Acquaviva refers to Valtrino's "saintly desire" for Japan in one of his replies: Acquaviva to Giovanni Antonio Valtrino in Messina, January 7, 1589, ARSI, Sic. 3, fol. 199v.

${ }^{24}$ This is what the general himself maintained upon his resolution of removing Valtrino from Sicily: Acquaviva to father provincial in Messina, June 15, 1591, ARSI, Sic. 3, fol. 290v .

${ }^{25}$ Aloysius (Luigi) Gonzaga died on June 21, 1591 at the age of twenty-three and was beatified in 1605 under Paul V (r.1605-21) and canonized in 1726 by Benedict XIII (r.1724-30). Following the advice of Roberto Bellarmino (Aloysius's spiritual director), Cepari had begun to gather materials and information on Aloysius's exemplary life before his death. The project of an extended and detailed biography was never abandoned by Cepari, who published the ultimate version after Aloysius's beatification. For essential details, see Gualberto Giachi, "Gonzaga, Luis," DHCJ, 2:1779-80. ${ }^{26}$ Virgilio Cepari, "L'autore dell'opera al pio lettore," in Vita del beato Luigi Gonzaga della Compagnia di Giesù (Rome: Appresso Luigi Zannetti, 1606). For some biographical information on Cepari, see Antonio M. Pignatelli, “Cepari, Virgilio,” DHCJ, 1:733-34.
} 
to the noble and virtuous novice, an account that circulated among the Jesuit communities in manuscript form, though it was soon superseded by Cepari's official biography. ${ }^{27}$

At least two points are worth noting here. The first concerns Valtrino's assignment once back in Rome. As Cepari reported, Valtrino was tasked with composing "the Chronicles of the Society," probably thanks to the expertise he had gained by editing the annual letters and searching for archival documents in Rome. The second relates to the word "chronicles." The term likely hinted at the archetype set by Juan Alfonso de Polanco's Chronicon Societatis Iesu (Chronicles of the Society of Jesus), which paused at 1556 (the year of Ignatius's death) and would need to be continued by someone else, according to Polanco himself.

Although it is indeed likely that Cepari was alluding to Polanco's magnum opus, the reference nevertheless needs further explanation. According to the author, the Chronicon Societatis Iesu contained the materials to write not one but four different historiae: (1) a general and universal history of the Society, (2) a history of the order's colleges throughout the world, (3) a history of the most eminent Jesuits, and (4) a sort of practical treatise on the government of the order based on the founder's example. ${ }^{28}$ It can thus be assumed that the "chronicle" of which Cepari spoke referred to the proper extensive history of the Society, while the writing of biographies of eminent Jesuits corresponded to a distinct historiographical enterprise, inseparable but different from the general "chronicle" of the Society, an overall narrative in which such illustrious examples would be included and reduced in length.

Archival research has revealed that Valtrino had begun writing drafts and biographical sketches, presumably conceived as materials for his historiographical duties. Due to the concern of the Society with memorialization and recording the life experience of its members, in the 1590s Valtrino came to gather information on Jesuit martyrs. ${ }^{29} \mathrm{He}$ also composed a Latin report of Acquaviva's election, apologetic in tone and based on factual accounts and prodigious circumstances, which

\footnotetext{
${ }^{27}$ Writing to the superior general, Valtrino stated that he had received many requests from Naples to send copies of his version of Gonzaga's life; see Giovanni Antonio Valtrino to Claudio Acquaviva, Siena, October 5, 1596, ARSI, Ital. 161, fols. 314-15. At present, four different manuscripts of Valtrino's work have come out: two are in ARSI (Vitae 14 and 14a), one in the National Library "Marciana" in Venice (Cod. It. XI, 184 [7414]) and one in the Library "Trivulziana" in Milan (Cod. 321). The exemplar from the "Marciana" has been published: Vita di Luigi Gonzaga della Compagnia di Giesù, ed. Gianluigi Arcari (Mantua: Gianluigi Arcari Editore, 2006).

${ }^{28}$ Juan Alfonso de Polanco, Chronicon Societatis Iesu (Madrid: Typographorum Societatis, 1894), 1:7-8; Guido Mongini, Maschere dell'identità: Alle origini della Compagnia di Gesù (Rome: Edizioni di storia e letteratura, 2016), 31-32.

${ }^{29}$ Catalogus quorumdam de Societate Iesu quipiam in causa sunt ad impiis interfecti: P. Jo. Antonius Vatrinus colligebat, ARSI, Vitae 5, fols. $18^{\mathrm{r}}-29^{\mathrm{r}}$. Valtrino's catalog of the Jesuit martyrs is also attested in the correspondence where Valtrino writes that, as far as he knew, "in the Roman College,
} 
Francesco Sacchini would later use in his Historiae Societatis Iesu (Histories of the Society of Jesus) and Vita di Claudio Acquaviva (Life of Claudio Acquaviva). ${ }^{30}$

At the same time, Valtrino also began to work on Ignatius's life. In the footsteps of Polanco and his Chronicon Societatis Iesu (which opened with a life of Ignatius and continued with a far-reaching chronological account of facts and events affecting Jesuits around the world), Valtrino's portrayal of the founder was likely the starting point for that general history or chronicle for which Superior General Acquaviva had finally summoned him back to Rome. Analyzing the excerpts from the remaining text, some important characteristics can be remarked upon to shed some light on Valtrino's rationale and historiographical method.

First of all, although the author had inserted the titles of the chapters in Latin, it is written in the Italian language. From a chronological point of view, it starts from Ignatius's youth and his Basque milieu and stops in 1526, when Ignatius and his first companions moved from Barcelona to the University of Alcalà de Henares. The first book is composed of thirteen chapters, while the second book ends with the third chapter. Several clues and internal reminders prove that Valtrino intended to complete this job, ${ }^{31}$ though this was a purpose he never fulfilled. The reasons for the interruption are not clear-it is likely that other assignments (such as teaching at the Roman College and then in Siena and Florence) prevented him from completing the project within his lifetime (he died in 1601, at the age of fortyfive).

Valtrino's work remained unpublished until 1960, when it appeared in the third volume of the Fontes narrativi de S. Ignatio de Loyola et de Societatis Iesu initiis (Narrative sources on St. Ignatius of Loyola and the beginnings of the Society of Jesus). ${ }^{32}$ Presumably, writing a new biography of the co-founder of the Society was as prestigious a task as it was arduous, particularly as at least four important and full-length biographies of Loyola were already available by the early 1590s, and hence there was a well-established historical tradition to confront. In 1572, Ribadeneyra had published the Vita Ignatii Loyolae (Life of Ignatius of Loyola) in

\footnotetext{
there are many copies of the martyrs of the Society extracted from an exemplar that I gave to the secretary, Father Ximenes, many years ago"; Valtrino to Claudio Acquaviva, Siena, October 5, 1596, ARSI, Ital. 161, fols. $314^{\mathrm{r}-\mathrm{v}}$.

${ }^{30}$ Giovanni Antonio Valtrino, Quaedam digna scitu quae acciderunt in electione R.P. Claudii Acquavivae, ARSI, Vitae 146, fols. 23 ${ }^{\mathrm{r}}-29 \mathrm{bis}$. For its use by Sacchini, see Francesco Sacchini, Historiae Societatis Iesu, pars quinta sive Claudius, tomus prior, Res extra Europam gestas et alia quaedam supplevit Petrus Possinus ex eadem Societate (Rome: Ex Typographia Varesij, 1661), 38, and Vita di Claudio Acquaviva, in Alessandro Guerra, Un generale tra le milizie del papa (Milan: F. Angeli, 2001), 165-290, here 213-16.

${ }^{31}$ In different passages, Valtrino refers to parts or chapters still to come; see Fontes narrativi, vol. 3, Narrationes scriptae ab anno 1574 ad initium saeculi XVII, ed. Cándido de Dalmases (Rome: Apud Monumenta Historica Societatis Iesu, 1960), 364, 365, 390.

${ }^{32}$ See Fontes narrativi, 3:334-38 for the critical note, and 338-91 for the text of the Vita authored by Valtrino.
} 
Latin, followed by a much-expanded Castilian edition in 1583 and another Latin revision in 1586; Giovanni Pietro Maffei released his version in an elegant humanist Latin in $1585 .{ }^{33}$ Besides the printed works, Ignatian historiography could also count on other contributions, namely the manuscript tradition dating back to an early stage of the order's history. ${ }^{34}$ As is well known, unlike other religious orders, from the very beginning the Jesuits paid great attention to their early history and began to develop their own historiography soon after the order's foundation. ${ }^{35} \mathrm{Ap}$ proved in September 1540 by Paul III (r.1534-49), the Society had already produced its first important historical documents by 1547 and 1548, i.e., Diego Laìnez's Epistola de Patre Ignatio (Epistle on Father Ignatius) and Juan Alfonso Polanco's Summarium hispanum de origine et progressu Societatis Iesu (Spanish summary of the origin and progress of the Society of Jesus). ${ }^{36}$

Other records then followed. There was the Chronicon of Polanco with his Vita Ignatii in Latin mentioned above; several writings by Jerónimo Nadal containing biographical and historical information; Polanco's Summarii italici (Italian summaries); writings by Ribadeneyra such as De actis Patris Ignatii (On the acts of Father Ignatius); ${ }^{37}$ the controversial Commentarium de origine et progressu Societatis Iesu (Comment on the origin and progress of the Society of Jesus) by Simon Rodrigues; and, above all, the so-called autobiography of Loyola or Acta Patris Ignatii (Acts of Father Ignatius). ${ }^{38}$

Dating back to the years 1553-55, the Acta Patris Ignatii were welcomed and reverenced by all those who had access to them. Always kept in manuscript form, this work had been eagerly copied and read, in full or in part, by Jesuits throughout Europe until 1567, when Superior General Francisco de Borja (in office 1565-72), at Ribadeneyra's suggestion, ordered that biographical material on Loyola, and particularly all copies and extracts of the Acta Patris Ignatii, be requisi-

\footnotetext{
${ }^{33}$ The biographies of 1572 and 1583 are available in Pedro de Ribadeneyra, Vita Ignatii Loyolae: Textus latinus et hispanus cum censuris (Rome: Apud Monumenta Historica Societatis Iesu, 1965); for Maffei's biography, see Giovanni Pietro Maffei, De vita et moribus Ignatii Loyolae (Rome: Apud Franciscum Zannettum, 1585).

${ }^{34}$ Most of the biographical materials on Loyola are contained in the three volumes of the Fontes narrativi mentioned above.

${ }^{35}$ Franco Motta, "La compagine sacra: Elementi di un mito delle origini nella storiografia sulla Compagnia di Gesù," Rivista storica italiana 117, no. 1 (2005): 5-25; Guido Mongini, "Censura e identità nella prima storiografia gesuitica (1547-1572)," in "Nunc alia tempora, alii mores": Storici e storia in età postridentina, ed. Massimo Firpo (Florence: Olschki, 2005), 169-88.

${ }^{36}$ On these early documents, see Mongini, Maschere dell'identità, 5-24.

${ }^{37}$ See Fontes narrativi, vol. 2, Narrationes scriptae annis 1557-1574, ed. Cándido de Dalmases (Rome: Apud Monumenta Historica Societatis Iesu, 1951), 317-94.

${ }^{38}$ See Mongini, Maschere dell'identità, 3-33, 98-112 (for Nadal's texts) and 352-57 (for Rodrigues's Commentarium). Almost all the cited titles are in Fontes narrativi, vols. 1-3, except for some writings of Nadal. For these, see Jerónimo Nadal, Commentarii de Instituto Societatis Iesu (Rome: Apud Monumenta Historica Societatis Iesu, 1962).
} 
tioned and sent to Rome. The reason for doing so was simple, as Ribadeneyra himself explained to a perplexed and very upset Nadal: it was necessary to remove from circulation - inside the Society - a text that could cause embarrassment because of the sincerity of expression of Ignatius himself, and that also, in Ribadeneyra's opinion, contained some inaccurate details. That text was to be replaced by the new Vita authored by Ribadeneyra on Borja's commission, the first official and approved history of Ignatius's life.

Though admitted only reluctantly and in allusive ways, it was evident that the general operation of internal self-censorship was aimed at clearing the way for a more institutional, controlled, and orthodox profile of the Society's founder while getting rid of alternative biographical-memorial traditions that could affect or hinder the affirmation of Loyola's official image. However, the operation, which was eventually carried out, does not mean that Ribadeneyra and Borja intended to erase, much less deny, the extraordinary and controversial aspects that had characterized Loyola's life and religious experience. It was rather a matter of opportunity and caution. In the Italian peninsula of the second half of the 1560s and early 1570s, Pope Pius V (r.1566-72), a faithful follower of Paul IV Carafa (r.1555-59), founder of the Roman Inquisition and clear antagonist of Ignatius and the Jesuits, was determined to support and impose the ideology of the Counter-Reformation. In such a climate of growing intransigency, there was little room to insist on the inspirations and inner illuminations of Ignatius as the core of the Society's identity. It was much more prudent to conceal, disguise, and expunge from the founder's official profile all those elements that could arouse suspicions and thicken the dark shadow that had been looming over Ignatius since 1526. This was the long shadow of the suspicion of alumbradismo, which chased Ignatius and his companions from Spain to France and Italy, as attested by the number of inquisitorial investigations and trials they had to face.

Although further research is needed to explore the vast project of memorykeeping and identity-building that was undertaken during Borja's generalate, a couple of observations can here be advanced on the basis of Ribadeneyra's work. In 1583, in a partly changed historical climate and different context, the aged Jesuit published a much larger Castilian edition of Ignatius's life in which he re-inserted facts and events omitted from the 1572 edition. These facts were mostly about Ignatian illuminist and charismatic religious experiences and his clashes with the Inquisition, facts Ribadeneyra knew well but had decided not to mention a decade earlier.

Furthermore, it is worth stressing that Ribadeneyra's Vita Ignatii of 1572, as well as the 1583 revision, had been the object of criticism and censure by the Jesuits themselves, which eventually prompted Superior General Mercurian to commission a new biography by Maffei in 1585. Even the latter, however, aroused 
criticism and censure, as it was regarded as too official and institutional; as well as some factual mistakes, Maffei's writing expunged and neglected certain details of Loyola's religious experiences, which meant that it lacked any trait of the Jesuit identity that found its distinguishing and quintessential characteristics in the instance of the founder.

As mentioned above, the intention of drawing up a biography of the founding father was a delicate matter. An enormous amount of prestige and a halo of holiness surrounded the name of Loyola. Inside the Society, he was venerated and considered the eponymous hero of the order that in the early 1590s had numbered six thousand members and was present in almost every corner of the globe. At the same time, half a century from its foundation, the whole of the Society was still fighting for legitimation while facing a serious and dramatic crisis. In such a situation, it was imperative to avoid any potential missteps. Given the issues at stake, some of Valtrino's historiographical choices seem particularly relevant. Following the edition of the Fontes narrativi, Valtrino used six main sources. ${ }^{39}$ As is to be expected, he drew on the biographies of Ribadeneyra (the first edition of 1572, and especially that of 1586) and (in a very limited way) of Maffei (such as mistakenly postponing the date of Ignatius's birth to 1495 instead of 1491). He also drew on the Vita Ignatii in Polanco's Chronicon, as well as the manuscript De actis Patris Ignatii penned by Ribadeneyra in $1559-66 .{ }^{40}$

Two other important and controversial sources are worthy of attention. The first is Nadal's unfinished Apologia pro Exercitiis S.P. Ignatii (Apology for the Exercises of S. Father Ignatius), composed in $1554-56 .{ }^{41}$ Here, in a fierce piece of writing, the Majorcan Jesuit responded to the accusations of heresy launched by some of the Spanish Dominicans. In doing so, the author employed an unusually aggressive tone for a master (and theorist) of the Jesuit rhetoric of nuestro modo de hablar (our way of speaking), attacking the Dominican inquisitors and reproaching them for being "men without Spirit," almost as heretical as the Lutherans and therefore unable of understanding the spiritual profile of Loyola. Nadal also defended every aspect of the Ignatian Spiritual Exercises, officially approved by Pope Paul III in 1548: against the accusations of alumbradismo alleged by the Dominican censors, he stated that Ignatius had been truly enlightened by God and proclaimed

\footnotetext{
${ }^{39}$ See Fontes narrativi, 3:336-38.

${ }^{40}$ Further investigations might detect Polanco's Summarium hispanum among the historical references Valtrino used for his Ignatian biography; in the absence of a more in-depth comparative analysis, I simply point it out as a hypothesis.

${ }^{41}$ For the text of the Apologia, see Jerónimo Nadal, Epistolae P. Hieronymi Nadal Societatis Iesu ab anno 1546 ad 1577 nunc primum editae et illustratae a Patribus ejusdem Societatis (Madrid: Typis Gabrielis Lopez del Horno, 1905), 4:820-26; for other references, see Polanco, Chronicon, 3:525-73; Nadal, Epistolae, 4:826-73.
} 
the full legitimacy of the peculiar religious experience of the founder as the true and sole bedrock for the whole Society and its devotees. ${ }^{42}$

As said, it was an unfinished work. In manuscript form and unpublished for centuries, it was prudently marginalized because of its vehemence and, even more, because of its tenets: in his defense of the Ignatian legacy, Nadal had openly declared the illuminist nature of Loyola's religious experience and acknowledged it as the only and authentic root of all the Society's features, from its hierarchical structure to the formation of its members in colleges, from the contemplative methods of the Exercises to the missionary strategies toward the infidels.

However, the presence of Nadal's Apologia among Valtrino's historical sources suggests that the text still circulated within the order and that it was considered authoritative and reliable on one crucial point about Ignatius's life and the Society at its origins. Indeed, the biographer drew on Nadal's Apologia pro Exercitiis to recall the circumstances and methods of the composition of the Spiritual Exercises, the fundamental guide for all the Jesuits. ${ }^{43}$

But if Valtrino showed remarkable independence of judgment in turning to that controversial text (by showing his general adherence to Nadal's thought), his intellectual autonomy also emerged in the decision to draw on another controversial authority: the autobiography of Ignatius cited above. In this regard, it should be stressed that Valtrino's redactions went far beyond the simple translation and collection of extracts, as the editor of the Fontes narrativi meant by asserting that Valtrino "saepe [...] nihil aliud facit, nisi Acta in sermonem italicum transcribere" (time and again, he does nothing else but transcribe the Acta in Italian vernacular). Indeed, "transcribing in Italian vernacular" long passages of the autobiographical Acta Patris Ignatii was one important intellectual gesture, perhaps the most significant, made by Valtrino in composing his biography of Loyola. As already recalled, all the copies of the Acta Patris Ignatii had been seized by the Roman curia at the general's order in 1567. From that date, the text had disappeared from inside the Society, and its dissemination and reading came to a halt. Ribadeneyra had already reintegrated parts of the Acta, citing them more or less indirectly in his biographies of 1583 and 1586, but in the following decade, Valtrino pushed forward their reintroduction. Faithfully transcribing full extracts of Ignatius's autobiography, the exact words of the founder circulated again - even without explicit references or quotations; the ecstasies, the mystical visions, and, first and foremost, the inner illuminations of the founder of the Society resounded with the same words by which he had dictated them. In this sense, Valtrino's editorial selection expressed the desire

${ }^{42}$ See Mongini, Maschere dell'identità, 301-9, where the issue of Nadal's thought is argued in detail.

${ }^{43}$ See Fontes narrativi, 1:404. For the central role that the Ignatian Exercises had during the "Acquaviva era," see Pierre-Antoine Fabre and Patrick Goujon, "The Spiritual Exercises in the Development of the Society of Jesus," in Fabre and Rurale, Acquaviva Project, 29-42. 
to stick to the outstanding spiritual experience of the founder and to bring it back to his confrères' acknowledgment.

\section{Writing Jesuit Vocations}

After he entered the Society, Valtrino began to assemble information about his companions. He compiled a series of life tales under the heading of Marvelous Vocations with the purpose of glorifying "God and the saints" and giving "spiritual consolation to [his] dearest brothers." According to the author's annotation, the thirty chapters (actually twenty-nine, for the thirtieth remained just a title in the table of contents) had two aims. The first (Ad Dei Sanctorumque gloriam [For the glory of God and the saints]) was accomplished through the lives of the Society's members who received the divine call and answered to it. The single episodes are focused on the elaboration of individual paths through various stages: the secular life before the vocation, the acceptance of the Lord's call, and the acquisition of the necessary virtues thanks to God's grace to overcome temptations, human weaknesses, and the opposition of the original family. Annotations on particular lives after crossing the threshold of the Society are scarce and mostly concern the time and circumstances of the protagonist's death. In general, the narrative focuses on the progression toward the "new life in religion," a process supervised by the constant presence and providence of God's Spirit. As to the second purpose (ad spiritualem carissimorum fratrum consolationem [for the spiritual consolation of the dearest brothers]), the term "spiritual consolation" is reminiscent of that "interior movement in the soul" that, in Ignatius's words, is the sign par excellence of the manifestation of God's will and approval. ${ }^{44}$ Following the Ignatian definition, Valtrino's accounts of Jesuit lives, sparkling with divine grace as they are, were intended to encourage and stimulate meditation in order to trigger off that consolatory effect of peace in God.

Considering the context in which Valtrino compiled his collection, we can guess the brethren he was addressing. As mentioned, Valtrino began to collect information soon after entering the Society and enrolling in the Roman College; first as a novice, then as a scholar and a member of the teaching staff, Valtrino knew the college system well together with its leading figures, internal customs, and procedures. It was from this setting that he took material for his Vocations. Most of the protagonists were actually based at the Roman College or were somehow related to it; some of them spent their entire existence there, being scholastics or professors;

\footnotetext{
${ }^{44}$ Loyola gave his definition of "consolation" in the Reglas para en alguna manera sentir $y$ conocer las varias mociones que en la ánima se causan; see Ignatius of Loyola, Exercitia spiritualia (Rome: Institutum Historicum Societatis Iesu, 1969), 376.
} 
others had been novices before moving to other institutions; while others returned there just before dying. Even the sources that Valtrino cited at the end of almost every chapter refer to the college context. Primary and secondary sources, oral and written information, are mostly related to the Roman institutions, where he was able to interview witnesses, recollect memories, listen to speeches (exhortationes), and read all sorts of documents, such as the epistolary correspondence he went through for the volumes of Litterae annuae mentioned above.

Identifying the addressees of the dedication may also help determine the readership of Valtrino's Vocations. The use of the term "brothers" refers to the manuscript having originally been intended ad intra, that is, for internal circulation only. To an audience mainly comprising students, seminarists, and novices, Valtrino intended to show portraits of Jesuits, exemplary in their manners, behavior, and virtues, not only to be emulated but also to be identified with. Some similarities and affinities in the individual vocational experiences could be recognized. The early doubts, the "burning" urge of the calling, the renunciation of the uncertainties and vanities of the material life, the role of confessors and spiritual fathers, and the opposition of friends and relatives, are recurring situations in Valtrino's tales, the happy endings of which were due to God's providence and grace. As we will see below, however, this was not necessarily a foregone conclusion: seven out of twenty-nine chapters show the opposite, ending in dramatic ways because of lack of abnegation and perseverance in listening to the Lord's call.

Overall, most of the stories describe successful vocations, despite perils, temptations, and impediments along the path. In these chapters, the protagonists are exemplars of zeal, humility, and obedience who pray assiduously (primarily mental orations) and are keenly devoted to the Virgin Mary and Jesus Christ. They stand as edifying models for the youth and the faithful; their vocations are punctuated with visitations, dreams, and heavenly inspirations that would have helped impress the readers' minds and increase the sense of wonder and divine providence in the otherwise ordinary life of each character.

Along with proposing virtuous exempla for pupils and novices, another reading of the stories is also plausible. I have been arguing that Valtrino's text was aimed at students and novices, principally of the Roman schools, although it may also have been aimed at students of other pedagogical institutions scattered throughout the Jesuit provinces. The issue of vocations was not only a question related to the promotion and recruitment of candidates; it was also a matter of procedures and how to handle admissions in the proper way, which meant testing the legitimacy of the vocation and accepting new members without discrediting the 
order. Already in his day, Ignatius had warned his companions of the risks of imprudent and hasty recruitment, especially among pupils of the Jesuit schools. ${ }^{45}$ Now, because of the fast growth of its membership, the increase of its ministries, the success of its institutions all over Europe and beyond, the Society had to take even more care in its recruitment policy.

The usual anti-Jesuit allegations against the fathers' modes and aims of recruiting surface in several parts of Valtrino's text. Jesuits are said to seduce and subjugate pupils behind their relatives' backs, their real goals being family goods and benefactors' revenues. Andrea Spinola, Alessandro di Nunzio, and Genuario Ducco are cases in point. Their families try to discourage them by resorting to innuendos and explicit accusations and eventually recur to civil and religious authorities, even to physical force and kidnap. ${ }^{46}$

In the first chapter, the young Innocenzo Fontana has to confront a series of ordeals and tribulations: over and over, he has to use all his strength and resolution to resist the repeated attacks from his relatives and other personages, who by blandishments and flatteries, manoeuvers and deception, menaces and open violence, try to deter him from his purpose. In order to dissuade Innocenzo, some warn him of the harsh life that awaits him inside the Society:

Although from the exterior, as you say, [the Jesuit religious life] seems large, nevertheless it is one of the most austere religions of our days; in fact, regarding the obedience, things are so narrow that it cannot even be told. Rules are so many and so strict that [the Jesuits] cannot make a step nor lift their eyes, so to speak, without breaking them. Mortifications are also so hard and the exercises so assiduous that quite often the veins break down and overstretch. ${ }^{47}$

Others complain about the promiscuity of the fathers: in the college at Modena, they maintain, "some women secretly chatted with them and misbehaved, and all this was publicly known," adding that the local fathers even misappropriated a certain sum of money that a faithful had temporarily entrusted to them. ${ }^{48}$ Locked in his room, besieged by his relatives, Innocenzo finds relief in mental prayers and holy scripture, appealing directly to God to "disband his enemies." 49 What Inno-

\footnotetext{
${ }^{45}$ Barton T. Geger, S.J., "Bending the Knee to Baal: St. Ignatius on Jesuit Vocation Promotion," Studies in the Spirituality of Jesuits 48, no. 2 (2016): 1-43, here 18-30.

${ }^{46}$ Two are cases in point: Innocenzo Fontana and Alessandro di Nunzio. See Valtrino, Vocazioni meravigliose, fols. $5^{\mathrm{r}}-35^{\mathrm{r}}$ and $86^{\mathrm{r}}-90^{\mathrm{v}}$, respectively.

${ }^{47}$ Valtrino, Vocazioni meravigliose, fols. $25^{\mathrm{v}}-26^{\mathrm{r}}$.

${ }^{48}$ Valtrino, Vocazioni meravigliose, fol. $33^{\mathrm{v}}$.

49 Valtrino, Vocazioni meravigliose, fol. $18^{\mathrm{r}}$.
} 
cenzo was enduring because of his vocation has the traits of a persecution, an allusion that was not accidental in Valtrino's work - as other archival evidence suggests. ${ }^{50}$ Moreover, the image recalls the "persecution paradigm" that Ribadeneyra, with Acquaviva's support, was then proposing as one of the founding features of Jesuit identity. ${ }^{51}$

Despite the repeated attacks against his resolution, Innocenzo stands firm. As his tribulations and suffering functioned as a means of testing his vocation, so his endurance and perseverance were signs of grace and divine providence.

Family opposition marked the vocation of the renowned Stanisław Kostka, first blessed of the Society (1605) and early patron of Jesuit novices and students. ${ }^{52}$ Once in Rome, the young Stanisław received letters full of anger from his father, who

besides many things that he wrote on the dishonor that he [Stanisław] had thrown upon his noble house by entering the Society, threatened him even more that, if Stanisław ever returned to Poland, he [Stanisław's' father] would have taken him out from any place and plied him with iron chains instead of the golden jewels that he was to offer him if he had remained in the world. ${ }^{53}$

Further and stronger opposition comes from devilish temptations and dreadful visions that beleaguer the dreams and meditations of the protagonists.

In all these sensitive situations, the Jesuit fathers show exemplary behavior. Valtrino portrays them as prudent, patient, respectful of the candidates' will and their family pretensions, and confident of the fair settlement of their disputes since the Society "has always been found innocent," although it has been persecuted by such allegations and even put on trial. ${ }^{54}$ Schoolteachers, confessors, spiritual fathers, and superiors are co-protagonists in Valtrino's stories since they play an essential part in the felicitous ending of vocations. They play an additional role, too:

\footnotetext{
${ }^{50}$ In ARSI, Vitae 5, for instance, there is another version of Innocenzo Fontana's vocational tale by Valtrino, entitled "Della persecuzione che patì un giovane che entrò nella Compagnia" [On the persecution a young man suffered for entering the Society], fols. $47^{\mathrm{r}}-53^{\mathrm{r}}$. In the same folder, at least two accounts, excluded from the collection Marvelous Vocations, bear the term "persecution" in their title: Claudio Seripando's (fols. 137 $-144^{\mathrm{r}}$ ) and Carlo Sangro's (fols. 144 ${ }^{\mathrm{v}}-147^{\mathrm{v}}$ ) lives.

${ }^{51}$ See Mongini, Maschere dell'identità, esp. 83-135, and Mongini, "Persecutions of the Jesuits," $43-57$.

${ }^{52}$ For a basic account, see Joseph Majkowski and Fergus O'Donoghue, "Kostka, Estanislao," DHCJ, 3:2219-20. On Kostka as the patron saint of youth (together with the aforementioned Aloysius Gonzaga), see Christina Jetter, Die Jesuitenheiligen Stanislaus Kostka und Aloysius von Gonzaga: Patrone der studierenden Jugend-Leitbilder der katholischen Elite (Würzburg: Echter Verlag, 2009).

${ }^{53}$ Valtrino, Vocazioni meravigliose, fol. $63^{\mathrm{r}}$.

${ }^{54}$ Valtrino, Vocazioni meravigliose, fol. $52^{\mathrm{v}}$.
} 
they bear testimony and keep memories of the events. We have already seen that Valtrino refers to his sources of information. Most of his stories, he states, are based on the accounts of fathers who heard them from the same protagonists, often on their deathbed. This is the case with Innocenzo Fontana, Giacomo Cerruto, Giovanni Maria Esaia, Alessandro di Nunzio, and Diego de Ledesma. The same also applies to twelve concise chapters, which are not vocational tales in a strict sense, for they are not accounts of the protagonists' acceptance of the divine call or the development of their vocations. If the longer episodes present the process in its early stage (manifestation, awareness, and acceptance), the shorter ones focus on its conclusion. These are tales of "good deaths." In line with the traditional necrologies (the obituaries that from the 1560s were recorded and developed in the following century as Jesuit "menologues" usually read in the refectory), ${ }^{55}$ these tales describe the culmination of lives spent inside the Society, the result and proof of authentic vocations. The sketches include men such as the scholastic Ercole Cavedoni from Ferrara. On the day of Ercole's death, his father and aunt, both devotees of the Society, saw a vision of him that gave them such a "marvelous consolation" that to Ercole's father it seemed "not so much to have lost a son on earth, as to have gained an advocate in heaven." 56 The sign of the blessing of Fabrizio Vignes from Naples was marked on his death by a sort of miracle concerning some little pastries ("ciambellette" in Italian), which had required an extraordinary lower amount of flour than usual. ${ }^{57}$ Others finished their lives inside the Society, and their brothers preserved the memory of the events of their demise, manifestations of their virtues and blessing. Such was the case with Giovanni Maria Oliverio's death. After spending his days helping the sick in Palermo during the great plague of 1575, Giovani Maria was found dead in his room, which no one had entered, yet his corpse was so orderly dressed and perfectly laid out on the bed that the brothers maintained only angels could have done it. ${ }^{58}$ Father Giovanni Maldonado died soon after accomplishing his commentary on the Gospels, as he had been told would be the case by a celestial vision years earlier. ${ }^{59}$ Egidio de Berghe, Leone Giglio, Stefano Genovese, and Giacomo Filippo Transimanno all died peacefully after recounting celestial visions and dreams of fighting (and defeating) the devil. ${ }^{60}$ On their respective deathbeds, the professor of theology Diego Paez and the ex-rector of the Roman

\footnotetext{
${ }^{55}$ See Robert Danieluk, “'Ob communem fructum et consolationem': La genèse et les enjeux de l'historiographie de la Compagnie de Jésus," Archivum historicum Societatis Iesu 75 (2006): 2962, here 52; Miriam Turrini, "I racconti della vocazione nel 'Menologio' del gesuita Giuseppe Antonio Patrignani (1730)," in La fede degli Italiani: Per Adriano Prosperi, ed. Guido Dall'Olio, Adelisa Malena, and Pierroberto Scaramella (Pisa: Edizioni della Normale, 2011), 1:253-64.

${ }^{56}$ Valtrino, Vocazioni meravigliose, fol. $70^{\mathrm{v}}$.

${ }^{57}$ Valtrino, Vocazioni meravigliose, fol. $72^{\mathrm{v}}$.

${ }^{58}$ Valtrino, Vocazioni meravigliose, fols. $73^{\mathrm{v}}-74^{\mathrm{r}}$.

${ }^{59}$ Valtrino, Vocazioni meravigliose, fols. $80^{\mathrm{r}-\mathrm{v}}$.

${ }^{60}$ Valtrino, Vocazioni meravigliose, fols. $82^{\mathrm{v}}-83^{\mathrm{v}}, 83^{\mathrm{v}}-84^{\mathrm{r}}, 85^{\mathrm{r}-\mathrm{v}}, 103^{\mathrm{v}}-104^{\mathrm{v}}$.
} 
College Sebastiano Romei simply exulted with joy and gratitude at the news of their impending death; ${ }^{61}$ so did Genuario Ducco, an outstanding exemplar of forbearance during his severe and prolonged sickness. ${ }^{62}$

Valtrino shows the opposite side, too: when one abandons his vocation, all the good turns bad. As briefly explained, seven short chapters present failures or malas muertes (bad deaths). Worldly temptations, career ambitions, disobedience, and lack of perseverance, all feature in these concise stories. There is the coadjutor Antonio Argenta, who, "because of some temptations," fled from the Society before falling dead in a bakery shop where he was employed "without even the chance to invoke God's name." ${ }^{\prime 3}$ Mention is also made of Aurelio Lombardo, who left the order without his superiors' permission and suddenly died before he was able to be readmitted to the order. ${ }^{64}$ Another father, the Portuguese Simon Vierras, frustrated in his ambition to become a professed Jesuit, left the Society and joined the Augustinian order but, once in Sicily, was killed by bandits who left his body unburied to be torn by stray dogs. ${ }^{65}$ After abandoning their vocations, others ended their life violently outside the Society. Desperation or madness led Giovanni Cola Cacace to commit suicide, jumping from a public loggia in Naples. ${ }^{66}$ Pietro Segni was bitten by his own dog, and since the pet was rabid, he died rapidly and in despair. ${ }^{67} \mathrm{~A}$ restless adventurer, the ex-Jesuit Antonio Veneziano perished in an accidental fire while he was in prison.$^{68}$ Having joined the Society without his family's consent, Adriano Pellicano was pulled out, got married, and died falling into a deep well, where his body was accidentally found days later. ${ }^{69}$

The miserable ending of those who betrayed their original vocation was indeed a memento for others who had just answered the call. From these stories, God is almost absent: the malas muertes are in fact due to the personal decision to quit, and the causes of death are quite fortuitous and common (a dog bite, an accidental fall, a disease). The real misery consists in dying outside the Society. Thus, perseverance is essential to keep answering the divine call and accomplish the will of God; for that reason, divine support and the grace of zeal, endurance, and fortitude are frequently prayed for by Valtrino's characters in order to stress that vocation is not accomplished once and for all but requires real commitment and continual effort.

\footnotetext{
${ }^{61}$ Valtrino, Vocazioni meravigliose, fols. $86^{\mathrm{r}}, 105^{\mathrm{r}}$.

${ }^{62}$ Valtrino, Vocazioni meravigliose, fols. $95^{\mathrm{r}}-101^{\mathrm{v}}$.

${ }^{63}$ Valtrino, Vocazioni meravigliose, fols. $81^{\mathrm{v}}-82^{\mathrm{r}}$.

${ }^{64}$ Valtrino, Vocazioni meravigliose, fols. $82^{\mathrm{r}-\mathrm{v}}$.

${ }^{65}$ Valtrino, Vocazioni meravigliose, fol. 84v .

${ }^{66}$ Valtrino, Vocazioni meravigliose, fols. $84^{\mathrm{v}}-85^{\mathrm{r}}$.

${ }^{67}$ Valtrino, Vocazioni meravigliose, fols. $105^{\mathrm{r}-\mathrm{v}}$.

${ }^{68}$ Valtrino, Vocazioni meravigliose, fol. $105^{\mathrm{v}}$.

${ }^{69}$ Valtrino, Vocazioni meravigliose, fols. $105^{\mathrm{v}}-106^{\mathrm{r}}$.
} 
These last chapters are not only a series of gloomy tales. Albeit limited in length and number, it is likely that they should have functioned as a deterrent for pupils and novices who had just taken their resolution or were about to do so. The dismissal of members had been a serious concern of the Society's hierarchy since the foundation. ${ }^{70}$ In the last decades of the sixteenth century, the high figures of the dimessi (a broad category grouping those who defected from the order spontaneously or forcefully) represented a crucial issue in terms of the efficiency of the Society's recruitment policy and its reputation. To raise the standards of membership, to avoid or at least reduce the stream of defections, the examiners had to be stricter in their evaluation and more careful toward suitable candidates, getting to know their motives, intentions, inclinations - in a nutshell, the quality of their vocation. The inclusion in Valtrino's collection of such failed vocations, and the fact that he did not group them separately or thematically, may mean that the problem of dismissals (imposed or voluntary as they might be) overlapped with policy and procedures that concerned the whole Jesuit structure, from the top to rank-and-file and potential recruits.

It is worth noting that among many themes emerging from Valtrino's Marvelous Vocations, one is entirely lacking: martyrdom. If the absence of this topic can be explained by the author's choice of telling lives of students and scholars of the Jesuit colleges (no missionaries are included, the ones more prone to martyrdom), it is, however, a significant omission given the increasing importance of martyrdom for the sixteenth-century Society of Jesus. ${ }^{71}$ Evidently, martyrization as a possible end of the Jesuit vocation was beyond Valtrino's scope, even though he was certainly not unfamiliar with a theme so central to the high levels of the order, which was involved in discussing the same concepts of "sanctity" and "martyrdom" and defining their meaning from an institutional viewpoint. ${ }^{72}$

\section{Conclusion}

As mentioned at the beginning of this essay, during the unrestful decades of the late sixteenth century, the Society of Jesus had to confront several challenges. Civil and

\footnotetext{
${ }^{70}$ As shown by Sabina Pavone, "I dimessi dalla Compagnia negli anni del generalato di Francesco Borgia: Una nuova questione storiografica," in Francisco de Borja y su tiempo: Política, religión y cultura en la edad moderna, ed. Enrico García Hernán and María del Pilar Ryan (Valencia: Albatros Ediciones, 2012), 465-79; see also Prosperi, La vocazione, esp. 220-35.

${ }^{71}$ See Esther Jiménez Pablo, "El martirio en las misiones durante el siglo XVII: Devoción y propaganda política," Chronica nova 43 (2017): 139-65; Fernando Ciaramitaro, "Política y religión: Martirio jesuita y simbolización monárquica de las Marianas," Convergencia: Revista de ciencias sociales 78 (2018): 1405-35.

${ }^{72}$ Girolamo Imbruglia, "La milizia come 'maniera di vivere' dei gesuiti: Missione, martirio, obbedienza," Rivista di storia del Cristianesimo 15, no. 2 (2018): 271-84.
} 
religious powers (from Spanish king Philip II [r.1556-98] to pontiffs such as Sixtus V [r.1585-90] and Clement VIII [r.1592-1605]) attempted to exert control over the Society; rival religious orders and internal seditious factions expressed harsh criticism against the Jesuit order and asked for radical changes. The long de auxiliis dispute over grace provided further reasons for animosity and discord. If, on certain, critical points the interferences could not be contained (as with the Spanish pressures on the criteria for admitting new postulants), ${ }^{73}$ the fifth superior general Claudio Acquaviva nonetheless managed to preserve the integrity of the community overall. In the interior, to fix the fractures and secure cohesion, one strategy was to refasten the collective bonds around a core of values and practices and confirm a shared image for the whole Society.

The need to reknit the threads of Jesuit identity was one of the most urgent issues during the crisis of the Acquaviva era, which led to the elaboration of the official historiography by Niccolò Orlandini and Francesco Sacchini in the following century. The Jesuit Valtrino lived and operated in the early stages of the turbulence, and his works encapsulated some of the issues of that time. From the edition of the Litterae annuae to the draft biography of Loyola to the anthology of vocation tales, a common motif can be detected: the promotion of the Jesuit community and its "coniunctio animorum" (union of souls) through the memory and the examples of single confrères, from those of the past (starting from Ignatius, of course) to the present generations.

The Litterae annuae pertained to this perspective. Valtrino outlined his approach based on fraternal bonds, edifying emulation, and mutual improvement of all the Jesuit communities. In the introduction to the first volume, the editor gave an account of the reason for such an enterprise. He took on the task of creating a deposit of information from all the Jesuit provinces and facilitating its circulation among the members so that "they would be more united among themselves and inflamed more intensely to the emulation of the same deeds" (hac rerum communione, tum coniunguntur inter se magis, tum vero ad eadem aemulanda acrius inflammantur).${ }^{74}$ The ongoing transmission of news between provinces, colleges, and missions (appropriately selected and brought together within a common frame) was intended to serve as a community link, facilitating horizontal communication between the brethren; it also served to celebrate the Society's achievements both internally and externally through the "typographical offensive" launched and controlled by the Roman curia. In such terms, the Litterae annuae were not a work of history. They aimed to stimulate the spiritual improvement of the brethren through

\footnotetext{
${ }^{73}$ This pressure surrounded the controversy over Jesuits of converso ancestry; see Robert A. Maryks, The Jesuit Order as a Synagogue of Jews: Jesuits of Jewish Ancestry and Purity-of-Blood Laws in the Early Society of Jesus (Leiden: Brill, 2010).

${ }^{74}$ Annuae litterae Societatis Iesu anni MDLXXXI, 3.
} 
the principle of emulation (or aemulatio, the Jesuit pedagogic method par excellence) while simultaneously promoting the success of the Society for a general audience through the selection of the most extraordinary, noteworthy, and edifying elements. $^{75}$

The cultivation and transmission of memory played a fundamental role in all this. As is well known, the preservation of the past had characterized the Society since its foundation; in particular, the origins of the order and its founder Ignatius of Loyola soon became the focus of memorializing concerns. From the early 1570s, a new phase of Jesuit historiography opened, starting from the history of Ignatius. Valtrino also contributed to this operation, which was inaugurated with the publication of Ribadeneyra's Vita Ignatii Loyolae (1572). Commissioned under Borja, Ribadeneyra's biography brought to completion previous historical traditions; it was the result of extensive work on available sources and personal memories of the Jesuit who had entered the order in 1540, a direct disciple of Loyola. Discussions and controversies around it partly motivated Mercurian's decision to entrust Maffei with a new version (1585). Nonetheless, Ribadeneyra's text (especially the revised editions of 1583 and 1586) enjoyed unrivalled success and helped establish the master narrative for the order's collective identity in a time of progressive expansion and institutional consolidation of the Society and deepening contrast between the church of Rome and the Reformed confessions.

In such writings, ideology prevailed over historical reconstructions. Factual adherence and documentary analysis was subordinated to the conscious selection and reinterpretation of the past: Ignatius was presented as an example of the perfect Jesuit. Rather than factual reconstruction, the biographies offered an orthodox profile of Loyola in response to the new requirements of the post-Tridentine church and against the insidious and tenacious suspicions toward the Jesuit order and its innovative religious proposal.

We do not know why Valtrino failed to complete his work on Ignatius. His aim of recovering some of the elements of Jesuit identity that the previous authors had omitted and his decision to transcribe and translate into Italian long passages from the Acta Patris Ignatii revealed his intention to be faithful to the original religious experience of Ignatius. It was the same extraordinary experience to which Nadal had ascribed the entire model of the Society, as he had sustained in every way and in every place he had gone to explain the Jesuit identity to the same members of the order: following Nadal's expression, on the "light" and "grace" that Ignatius had received from God befell the vocation, and the life, of every Jesuit.

\footnotetext{
${ }^{75}$ According to a tendency implemented under the sixth superior general Muzio Vitelleschi (in office 1615-45); Annick Delfosse, "Les Litterae annuae de la Compagnie de Jésus entre compte rendu factuel et construction identitaire: L'exemple de Bruxelles," in Quatre siècles de présence jésuite à Bruxelles, ed. Alain Deneef and Xavier Rousseaux (Brussels: Édition Prosopon, 2012), 214-33; Danieluk, “'Ob communem fructum et consolationem,"” esp. 51-54.
} 
The same divine light and grace hover constantly in the vocational stories Valtrino gathered from the 1570s onward. The Vocazioni meravigliose belongs to the tradition of memorialist-edifying literature inside the early Society. And yet, Valtrino's manuscript is not just a collection of Jesuits' biographies in line with the recordkeeping practice of the Society; nor is it only a series of exemplary stories or emulative models to be read in classrooms or refectories. Instead, it is a "group portrait" of the Ignatian order and its way to perfection in a time when even its own members were questioning some of the hallmarks of the Jesuit forma vitae (form of life). In Valtrino's Vocazioni, there are some recurring features: frequent Communion, scheduled confession (which refers to Jesuit spiritual direction), oral and mental prayers, devout congregations (especially Marian ones), spiritual conversations, and the Spiritual Exercises. Implicitly, discernment has a central position, and not a few chapters contain clues of its practice applied to the vocation. In this respect, the spiritual father and the father confessor play a key part. They are often evoked by the protagonists of the stories and, even though the nature of the narrative does not allow modern readers to grasp their role in detail, they appear crucial in checking and guiding the candidates' resolution.

Other episodes emphasize the hierarchical structure of the Society and the principles of charity and obedience (also exalted by the opposite examples of the "dimessi"). More generally, the Jesuit way of life is presented as a "perfect life" because it combines one's own salvation with the help of souls. Its perfection depends on the nature of religio mixta, typical of the Society: a combination of contemplative and active apostolate "more similar to the life of Our Lord Jesus Christ," as one of Valtrino's protagonists affirmed. ${ }^{76}$

On the whole, all these aspects lack a detailed characterization in the narrative; they are only hinted at and suggested evocatively without further explanation. As veiled and elusive as they may be, the references to the peculiar traits of the Jesuit order in the narrative recall a complex and articulated ideological system, which concerned general assumptions of the religious experience of the order's members, as well as the institutional organization of the Society and the concept of vocation to it. The very nature of such a vocation implied the sense of "marvel"

\footnotetext{
${ }^{76}$ Valtrino, Vocazioni meravigliose, fol. $79^{\mathrm{r}}$. The hybrid character of the Society, "more perfect" than active or contemplative orders, was maintained and defended by exponents such as Roberto Bellarmino against the multiple complaints from external opponents and internal members too; see Franco Motta, "Jesuit Theology, Politics, and Identity: The Generalate of Acquaviva and the Years of Formation," in Fabre and Rurale, Acquaviva Project, 353-74, here 356-57. In Valtrino, the perfection of the Jesuit option was motivated by its adherence to Jesus's life, evoking the image of the imitatio Christi. For the profound implications of that concept, and the apostolic model of the early church it implied, see Guido Mongini, "Para solos nosotros": La differenza gesuitica; Religione e politica tra Ignazio di Loyola e Claudio Acquaviva (Alessandria: Edizioni dell'Orso, 2019), esp. 321.
} 
Valtrino attributed to his stories. As argued earlier, Valtrino's vocations are "marvelous" not because of miraculous events or any particularly exceptional circumstance but because of their inherent essence: God originated them and in them his Spirit operated. The divine origin determined the extraordinary quality of the Jesuit vocations portrayed by Valtrino. From Ignatius to the following generations of socii, God acted by summoning individuals to become instruments of his will, which could and should be ascertained through the practice of the Ignatian Exercises, the means "para buscar y hallar la voluntad divina" (to seek and find the divine will). ${ }^{77}$ Hence descended the certainty of the Jesuit vocation as the fruit of God's will; hence the Society, a religious body of individual vocations of divine origin, acquired a sacral status and formed (in all its disciplinary and organizational aspects) a true "work of God," una obra de Dios, as Ribadeneyra would have maintained. ${ }^{78}$ Although less explicitly and powerfully than the authoritative elderly disciple of Loyola, Valtrino worked out some of the fundamentals of the earliest Jesuit identity in a momentous time for the entire Society of Jesus, one in which its cohesion, and even its very survival, were endangered and its distinctive features met with piercing criticisms and misunderstandings from inside the Society itself.

\footnotetext{
${ }^{77}$ Ignatius of Loyola, Exercitia spiritualia (Rome: Institutum Historicum Societatis Iesu, 1969), 142 .

${ }^{78}$ In his Tratado de las persecuciones, written between 1602 and 1606. For a discussion of Ribadeneyra's treatise and its significance within the early Society of Jesus, see Mongini, "Persecutions of the Jesuits," 50-56, and Mongini, "Para solos nosotros," 143-59.
} 